Pflügers Arch (1993) 423:356-364

Eururopean Journal

of Physiology

(C) Springer-Veriag 1993

\title{
Oxygen-dependent expression of the erythropoietin gene in rat hepatocytes in vitro
}

\author{
K.-U. Eckardt ${ }^{1}$, C. W. Pugh ${ }^{2}$, P. J. Ratcliffe ${ }^{2}$, A. Kurtz ${ }^{1}$ \\ 1 Institute of Physiology, University of Regensburg, Universitätsstrasse 31, W-8400 Regensburg, Germany \\ ${ }^{2}$ Institute of Molecular Medicine, John Radcliffe Hospital, Oxford OX3 9DU, UK
}

Received October 6, 1992/Received after revision January 4, 1993/Accepted January 26, 1993

\begin{abstract}
Since in juvenile rats the liver is the predominant site of erythropoietin (EPO) gene expression, we have used primary cultures of juvenile rat hepatocytes to establish an in vitro system for investigation of oxygendependent EPO formation. When isolated hepatocytes were incubated at reduced oxygen tensions for $18-48 \mathrm{~h}$, we found increased secretion of EPO protein and elevated levels of EPO mRNA, as determined by RNase protection. This increase was maximal at $3 \% \mathrm{O}_{2}$, where EPO mRNA levels after $18 \mathrm{~h}$ were approximately 15fold higher than at $20 \% \mathrm{O}_{2}$. The increase in EPO mRNA at low oxygen tensions was specific insofar as $\left[{ }^{3} \mathrm{H}\right]$ uridine incorporation, as a measure of total RNA synthesis, was reduced by approximately $50 \%$ at $3 \% \mathrm{O}_{2}$, and it appeared to involve gene transcription since it was abolished in the presence of actinomycin $\mathrm{D}(35 \mu \mathrm{M})$. Significant increases in EPO mRNA were also observed in cells kept at $20 \%$ oxygen in the presence of cobalt chloride $(50 \mu \mathrm{M})$ and nickel chloride $(400 \mu \mathrm{M})$, but EPO mRNA levels achieved under these conditions were less than $7 \%$ of those in cells incubated at $3 \%$ oxygen. No increase in EPO mRNA levels was observed in cultures incubated at $20 \% \mathrm{O}_{2}$ in the presence of cyclic dibutyrylAMP $(10 \mu \mathrm{M}-3 \mathrm{mM})$, cyclic 8 -bromoGMP $(10 \mu \mathrm{M}-$ $1 \mathrm{mM})$, cyclohexyladenosine $(1 \mu \mathrm{M}), 5^{\prime}-N$-ethylcarboxamidoadenosine $(1 \mu \mathrm{M})$ and phorbol 12-myristate 13acetate $(3 \mathrm{nM})$. In the presence of $10 \%$ carbon monoxide, used to block haem proteins in their oxy conformation, EPO mRNA levels in hepatocytes incubated at low oxygen tensions were reduced to $63 \%$. Taken together, these findings indicate that oxygen-dependent control of the EPO gene in hepatocytes operates via intrinsic cellular oxygen-sensing mechanisms. Their signal transduction does not seem to occur via classical "second-messenger" pathways. A haem protein may be involved in oxygen sensing, but no conclusive evidence was obtained as to whether it is essential.
\end{abstract}

Correspondence to: K.-U. Eckardt
Key words: Erythropoietin - Hepatocytes - Rat - In vitro - Hypoxia - Signalling - mRNA - RNase protection

\section{Introduction}

Production of erythropoietin (EPO), the major regulator of erythropoiesis, is inversely related to oxygen availability of the organism [17]. Kidneys and liver are the physiologically important production sites of EPO and in both organs the major control of EPO formation has been shown to operate at the level of its mRNA [2, 4, 31]. EPO mRNA was detected in peritubular cells of the renal cortex $[18,22]$ and recently in parenchymal as well as non-parenchymal liver cells $[19,33]$. Changes in EPO mRNA are at least in part mediated through changes in the EPO-transcription rate [32], and analysis of human EPO gene expression in transgenic mice revealed that a sequence within the immediate $3^{\prime}$ flanking region of the gene is required for expression in hepatocytes, and that, in addition, a region between 6 and $14 \mathrm{~kb} 5^{\prime}$ of the gene directs expression in the kidneys [34].

Little is known, however, about the cellular mechanisms by which hypoxia controls the expression of the EPO gene. Efforts to explore these mechanisms have in the past been hindered by the lack of in vitro systems producing EPO in a regulated fashion. The significance of studies in various systems such as organ cultures of rat kidney [23, 25, 37] or mouse fetal liver [44], isolated glomeruli [5], renal mesangial cell cultures [20], renal tubular cell lines $[6,36]$, erythroleukaemic cells $[3,39]$, mouse spleen macrophages [28], fetal liver cells [21] and isolated Kupffer cells [26] remains difficult to interpret mainly for two reasons. First, demonstration of EPO production in these systems depended upon bioassays and/or inhibition of bioactivity by antibodies raised against impure preparations of EPO and, second, many of the cell types claimed to produce EPO have not been 
shown to express the EPO gene in vivo. More recently, Goldberg et al. [13] and subsequently other investigators $[8,41]$ reported the regulated expression of the EPO gene and production of EPO protein in the two human hepatoma cell lines Hep G2 and Hep 3B in response to hypoxia and certain divalent metals, which are known stimuli for EPO formation in vivo [15]. Moreover, circumstantial evidence was provided that the oxygen sensor regulating EPO in Hep 3B cells is a haem protein [14].

For further study of the oxygen-dependent control of EPO formation we attempted to establish an in vitro system using cells that are physiological production sites of EPO in vivo. Such a system should allow us to define the cellular characteristics of the oxygen-dependent control of EPO in vivo and should also allow the significance of findings so far obtained in tumor cell lines to be tested. Recently we have shown that, in contrast to what was previously anticipated, in rats the contribution of the liver to EPO formation under severe hypoxia is quite significant and amounts to about one-third in adults and to $80 \%-90 \%$ up to an age of 2 weeks [12]. We have therefore focussed on hepatic EPO formation and report here that fractionation of liver cells from hypoxic juvenile rats indicates that, as in adult animals $[19,33]$, hepatocytes are the major site of EPO gene expression in the liver, and, furthermore, that in hepatocytes isolated from normoxic juvenile animals, accumulation of EPO mRNA is inducible in vitro by hypoxia.

\section{Materials and methods}

Animals. Male Sprague Dawley rats aged 10-19 days (body weight $30 \pm 2 \mathrm{~g}$; mean $\pm \mathrm{SE}$ ) were used (Charles River Wiga, Sulzbach, Germany).

Liver cell isolation. Cells were isolated from livers using a twostage in situ perfusion via the portal vein [1] in a non-recirculating system. The basic perfusion medium consisted of Hanks buffered salt solution (HBSS; $137 \mathrm{mM} \mathrm{NaCl}, 3.7 \mathrm{mM} \mathrm{KCl}, 0.4 \mathrm{mM}$ $\mathrm{KH}_{2} \mathrm{PO}_{4}, 0.3 \mathrm{mM} \mathrm{Na} \mathrm{HPO}_{4}, 4 \mathrm{mM} \mathrm{NaHCO}{ }_{3}, 5.5 \mathrm{mM}$ glucose) and was supplemented with $10 \mathrm{mM}$ HEPES, $0.5 \mathrm{mM}$ EGTA (medium 1) or with $10 \mathrm{mM}$ HEPES, $5 \mathrm{mM} \mathrm{CaCl}, 0.1 \mathrm{mg} / \mathrm{ml}$ collagenase (0.287 U/mg, Boehringer Mannheim, Mannheim, Germany) (medium 2). After cannulation of the portal vein, livers were flushed with $1 \mathrm{ml}$ sodium heparin $(1000 \mathrm{U} / \mathrm{ml})$ then perfused with medium 1 for $5 \mathrm{~min}$ at a rate of $4.5 \mathrm{ml} / \mathrm{min}$ and subsequently with medium 2 for $8 \mathrm{~min}$ at a rate of $3.8 \mathrm{ml} / \mathrm{min}$. Perfusion media were preoxygenated and prewarmed to $37^{\circ} \mathrm{C}$. After excision, livers were immediately placed in ice-cold HBSS and cells were gently liberated into the buffer after opening of the liver capsule. The suspension was cleared of the connective tissue framework and remaining clumps of tissue by filtration through a $50-\mu \mathrm{m}$ nylon sieve.

Differential centrifugation of liver cells. Fractions of parenchymal and non-parenchymal liver cells were prepared from animals exposed to $7 \% \mathrm{O}_{2}$ for $7 \mathrm{~h}$ prior to liver cell isolation using differential centrifugation, exactly as described by Doolittle and Richter [10]. Fractionation was carried out at $4^{\circ} \mathrm{C}$ and comprised five centrifugation steps at $50 \mathrm{~g}$ to pellet hepatocytes and four centrifugations of the supernatant at $500 \mathrm{~g}$, alternating with four at $50 \mathrm{~g}$ to pellet non-parenchymal liver cells and remove residual hepatocytes. One-third of the single-cell suspension used as starting material was removed prior to separation, kept at $4^{\circ} \mathrm{C}$ during the separation, and snap-frozen in liquid nitrogen together with aliquots of the parenchymal and non-parenchymal fraction prior to RNA extraction.

Cell culture. After isolation and two washes at $90 \mathrm{~g}$ in ice-cold HBSS, cells were suspended in minimal essential medium (Gibco BRL, Life Technologies, Eggenstein, Germany), supplemented with $10 \%$ fetal bovine serum (Gibco), glutamine ( $2 \mathrm{mM}$ ), penicillin $(50$ units $/ \mathrm{ml})$, streptomycin sulphate $(50 \mu \mathrm{g} / \mathrm{ml})$, insulin $(10 \mu \mathrm{g} /$ $\mathrm{ml})$ and hydrocortisone $(2 \mu \mathrm{g} / \mathrm{ml})$ and were routinely plated at a density of $(8-11) \times 10^{4}$ cells $/ \mathrm{cm}^{2}$ in $175-\mathrm{cm}^{2}$ dishes. After $4 \mathrm{~h}$ incubation at $20 \% \mathrm{O}_{2} / 5 \% \mathrm{CO}_{2} / 75 \% \mathrm{~N}_{2}$, to allow cell attachment, the culture medium was removed together with the majority of nonattached cells, which consistently comprised less than $10 \%$, and cultures were refed the same medium without serum supplementation. Subsequent incubation was carried out for $18-48 \mathrm{~h}$ at $1 \%$, $2 \%, 3 \%, 5 \%$ or $20 \% \mathrm{O}_{2} / 5 \% \mathrm{CO}_{2}$ /balance $\mathrm{N}_{2}$ in waterjacketed incubators (models 3319 and 3336, Forma Scientific, Marietta, Ohio 45750 , USA). Oxygen tensions in the incubators were verified using an oxygen electrode (Eschweiler, Kiel, Germany). Six to eight dishes were prepared from the cells isolated from one animal and in each experiment at least one dish was always kept at $3 \%$ $\mathrm{O}_{2}$ and $20 \% \mathrm{O}_{2}$, thus providing internal controls for the different conditions studied. In pharmacological studies substances were added to the serum-free culture medium as follows: $\mathrm{CoCl}_{2}(10-$ $100 \mu \mathrm{M}), \mathrm{NiCl}_{2}(50-400 \mu \mathrm{M}), \mathrm{MnCl}_{2}(50-600 \mu \mathrm{M})$, 8-bromoguanosine cyclic $3^{\prime}, 5^{\prime}$-monophosphate $(0.01-1 \mathrm{mM}), N$-2'-O-dibutyryladenosine cyclic $3^{\prime}, 5^{\prime}$-monophosphate $(0.01-3 \mathrm{mM})$, forskolin $(10 \mu \mathrm{M}), N$-cyclohexyladenosine $(1 \mu \mathrm{M}), 5^{\prime}-N$-ethylcarboxamidoadenosine $(1 \mu \mathrm{M})$, phorbol 12-myristate 13 -acetate $(3 \mathrm{nM})$, actinomycin D $(35 \mu \mathrm{M})$. Cycloheximide $(200 \mu \mathrm{M})$, 4,6-dioxoheptanoic acid $(2 \mathrm{mM})$ and desferrioxamine $(130 \mu \mathrm{M})$ were added during both preincubation with serum-containing medium and subsequent incubation in serum-free medium. In experiments with the latter two drugs, cells were preincubated for $24 \mathrm{~h}$ instead of $4 \mathrm{~h}$.

In a separate set of experiments designed to test the effect of carbon monoxide on EPO gene expression in hepatocyte cultures, cells were plated in $175-\mathrm{cm}^{2}$ flasks which were, after $4 \mathrm{~h}$ preincubation and change of medium, fitted tightly with a stainless-steel lid. Gas in- and outflow were provided by two steel tubes, which perforated the lid and were connected to two Silastic tubings at the outside of the flask. The flasks were flushed with premixed gases containing either $1 \% \mathrm{O}_{2}, 5 \% \mathrm{CO}_{2}$, balance $\mathrm{N}_{2}$ or $1 \% \mathrm{O}_{2}, 5 \%$ $\mathrm{CO}_{2}, 10 \% \mathrm{CO}$, balance $\mathrm{N}_{2}$, and, after the silastic tubings were sealed, the flasks were immersed in a $37^{\circ} \mathrm{C}$ constant-temperature water bath for $18 \mathrm{~h}$. At the end of the incubation the tight seal of the flasks was verified by measuring the oxygen tension inside.

Measurement of EPO mRNA. Cells were harvested with trypsin/ EDTA, snap-frozen in liquid nitrogen and stored at $-70^{\circ} \mathrm{C}$ prior to RNA extraction. RNA was prepared using a modified singlestep acid/guanidinium thiocyanate/phenol/chloroform extraction method (RNAzol B, Biogenesis, Bournemouth, England) and was assayed by RNase protection as described [27]. RNA probes were continuously labelled with $\left[\alpha^{32} \mathrm{P}\right] \mathrm{GTP}(410 \mathrm{Ci} / \mathrm{mmol}$; Amersham International, Amersham, UK) by SP6 polymerase, using a genomic rat EPO DNA template, which comprised a PstI-SacI fragment, containing 132 base pairs (bp) of exon $V$ and approximately $300 \mathrm{bp}$ of the adjoining intron. Between $44 \mu \mathrm{g}$ and $150 \mu \mathrm{g}$ total RNA was hybridized with $(0.25-0.5) \times 10^{6} \mathrm{cpm}$ radiolabelled EPO probe in $80 \%$ formamide $/ 40 \mathrm{mM} \mathrm{1,4-piperazinediethanesul-}$ phonic acid (PIPES), pH 6.4/400 $\mathrm{mM} \mathrm{NaCl} / 1 \mathrm{mM}$ EDTA at $60^{\circ} \mathrm{C}$ overnight, and RNase digestion was performed at $20^{\circ} \mathrm{C}$ for 30 $\mathrm{min}$. Protected fragments were subjected to denaturing polyacrylamide gel electrophoresis and quantified by measuring the radioactivity of excised portions of the dried gel in liquid scintillant $(1500$ Tri-Carb liquid Scintillation Analyzer, Packard Instrument Company, Downers Grove, IL 60515, USA). Equivalent amounts of yeast transfer RNA were run in each assay to assess background radioactivity. After background subtraction the radioactivity of each protected EPO mRNA fragment was divided by the quantity of total RNA analysed and expressed relative to an external stan- 
dard, as described [12], consisting of $1 \mu \mathrm{g}$ pooled RNA extracted from kidneys of severely anaemic adult rats, which was coanalysed with each gel and assigned an arbitrary value of 1 .

Determination of cell viability. Trypan blue exclusion was used as a parameter of cell viability. Aliquots of the suspension of freshly isolated cells in culture medium $(500 \mu \mathrm{l})$ were incubated together with $40 \mu 1$ phosphate-buffered saline (PBS) and 360 $\mu$ l trypan blue stock solution $(0.5 \%$ in $0.9 \% \mathrm{NaCl}$; Seromed, Berlin, Germany) for $3 \mathrm{~min}$ at $37^{\circ} \mathrm{C}$ and immediately thereafter the percentage of cells excluding the dye was counted under an inverted microscope using a standard counting chamber. To assess changes in viability of cultured cells, hepatocytes were incubated in $9.6-\mathrm{cm}^{2}$ dishes under conditions identical to those used for measurement of EPO mRNA. At the end of the 4-h preincubation period or after $18 \mathrm{~h}$ of subsequent incubation at $3 \%$ or $20 \%$ oxygen, the culture medium was removed, and the cells were incubated with $540 \mu \mathrm{l}$ PBS and $360 \mu \mathrm{l}$ trypan blue stock solution for $3 \mathrm{~min}$ at $37^{\circ} \mathrm{C}$. After removal of the supernatant the percentage of cells excluding the dye was directly counted in the culture dishes.

Measurement of total RNA synthesis. $\left[{ }^{3} \mathrm{H}\right]$ Uridine incorporation into trichloroacetic-acid $\left(\mathrm{Cl}_{3} \mathrm{AcOH}\right)$-insoluble material was used as a measure of total RNA synthesis as described [43], in cultures that were incubated under conditions identical to those used for measurement of EPO mRNA, except that $9.6-\mathrm{cm}^{2}$ dishes were used. In brief, $0.1 \mu \mathrm{Ci}\left[5-{ }^{3} \mathrm{H}\right]$ uridine $(28 \mathrm{Ci} / \mathrm{mmol}$, Amersham) was added to the dishes during the final $2.5 \mathrm{~h}$ of incubation at $3 \%$ or $20 \%$ oxygen. At the end of the incubation period the culture dishes were immediately transferred to a cold room. The cells were rinsed with $1 \mathrm{ml}$ ice-cold PBS, and the cell layers were covered with $3 \mathrm{ml}$ ice-cold $\mathrm{Cl}_{3} \mathrm{AcOH}(10 \%)$ to extract $\mathrm{Cl}_{3} \mathrm{AcOH}$-soluble nucleosides/ nucleotides in situ at $4^{\circ} \mathrm{C}$ for $50 \mathrm{~min}$. After washing the cells three times with cold $\mathrm{Cl}_{3} \mathrm{AcOH}(10 \%)$, they were dried at room temperature and digested in $1 \mathrm{ml} 1 \mathrm{M} \mathrm{KOH}$. Radioactivity was counted in liquid scintillant after neutralization with $1 \mathrm{M} \mathrm{HCl}$.

Measurement of protein synthesis. In a separate set of experiments protein synthesis was measured in parallel in insolated rat hepatocytes and the human hepatoma cells Hep G2, which were seeded in $9.6-\mathrm{cm}^{2}$ dishes at identical densities. Cells were incubated for $18 \mathrm{~h}$ in basal Eagle's medium without L-methionine (Gibco), supplemented with $10 \%$ fetal calf serum and $1.5 \mu \mathrm{Ci} /$ dish ${ }^{35} \mathrm{~S}$-labelled L-methionine $(>1000 \mathrm{Ci} / \mathrm{mmol}$; Amersham) in the absence and presence of $\mathrm{CoCl}_{2}(50 \mu \mathrm{M})$. Cell layers were treated as described for measurement of RNA synthesis to determine incorporation of labelled methionine into $\mathrm{Cl}_{3} \mathrm{AcOH}$-insoluble material. Incorporation of $\left[{ }^{35}\right.$ S $]$ methionine was related to cellular protein content. To this end the culture medium in parallel cultures was removed and after two washes of the cell layers with PBS, cells were lysed in $1 \mathrm{ml}$ PBS supplemented with $0.1 \%$ Triton X-100. Protein concentrations of cell lysates were determined with a commercially available protein assay (Bio-Rad) using bovine serum albumin as standard.

Measurement of EPO. EPO concentrations in tissue-culture supernatants, that were concentrated up to 15 -fold by ultrafiltration (Centrisart I, SM 13249, Sartorius, Göttingen, Germany) were measured by radioimmunoassay as described [11], using a pool of serum from hypoxic rats as standard after calibration in the in vivo bioassay [11].

Agents. Unless otherwise indicated agents were from Sigma (Sigma Chemical Company, St. Louis, MO 63178, USA).

Statistics. Student's paired $t$-test was used for comparison of EPO mRNA levels in culture dishes obtained from the same cell preparation, which were incubated and analysed in parallel. Scheffe's test (analysis of variance) was used to compare EPO mRNA levels in cultures that were not processed in parallel. $P<0.05$ was considered significant.
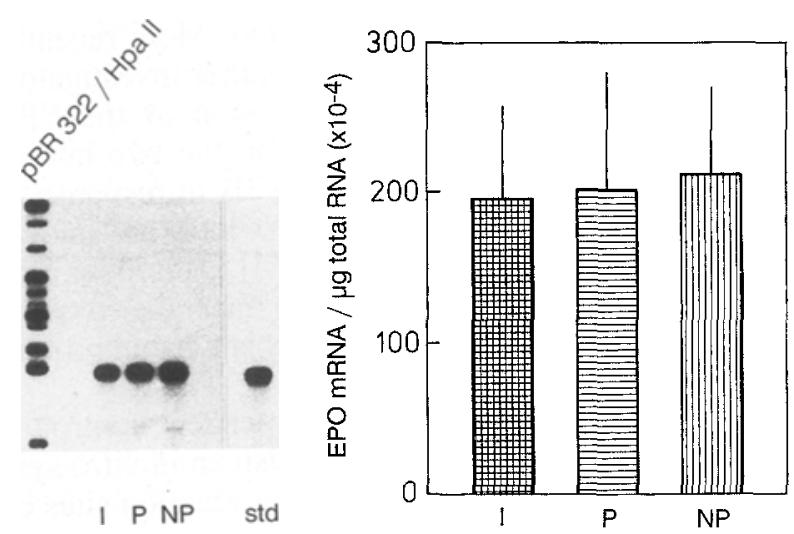

Fig. 1. Erythropoietin (EPO) mRNA in an initial, freshly isolated single-cell suspension of juvenile rat liver cells $(I)$ and in fractions of parenchymal $(P)$ and non-parenchymal $(N P)$ liver cells, prepared from the initial cell suspension by differential centrifugation. Left: autoradiograph of an RNase protection assay from one cellseparation experiment using $44 \mu \mathrm{g}$ RNA from each cell fraction and $1 \mu \mathrm{g}$ kidney RNA as external standard $(s t d)$. Right: quantitative analysis of EPO mRNA concentrations in initial $(I)$, parenchymal $(P)$ and non-parenchymal $(N P)$ cell suspensions in three independent experiments (mean $\pm S E$ ). For quantification, the radioactivity of protected EPO mRNA fragments was determined after excision from the dried gels, and was related to that of $1 \mu \mathrm{g}$ renal RNA from severly anaemic rats, which was coanalysed on each gel and assigned an arbitrary value of 1 , to obtain estimates of the concentration of EPO mRNA per microgram total RNA analysed. Prior to cell isolation animals were exposed to $7 \% \mathrm{O}_{2}$ for $7 \mathrm{~h}$

\section{Results}

\section{Differential centrifugation of liver cells obtained from hypoxic rats}

When viewed by phase-contrast microscopy freshly isolated liver cells appeared as a well-dissociated heterogeneous population, in which non-parenchymal cells could be differentiated from the much larger, occasionally binucleate hepatocytes. In accordance with previous studies $[10,42]$ differential centrifugation of the liver cell suspension resulted in a virtually pure fraction of hepatocytes, in which hardly any smaller cells could be detected, and a second fraction, significantly enriched in smaller, non-parenchymal cells. Using two-thirds of the cells isolated from one liver as starting material, the yield of total RNA in the parenchymal fraction was $994 \pm 137 \mu \mathrm{g}$ and in the non-parenchymal fraction $58 \pm 6.1 \mu \mathrm{g}$ (mean $\pm \mathrm{SE}, n=3$ ). As shown in Fig. 1, when equal amounts of RNA were assayed for the presence of EPO mRNA, similar signals were obtained in the initial cell suspension, the parenchymal and the nonparenchymal fraction. Although the non-parenchymal fractions showed $20 \%-30 \%$ contamination with hepatocytes, as estimated by differential counting using an inverted phase-contrast microscope, this could not account for an EPO mRNA level as high as in the parenchymal cells alone, suggesting that EPO mRNA is present in both hepatocytes and non-parenchymal liver cells. Considering, however, that removal of non-parenchymal cells from the starting material did not result in 


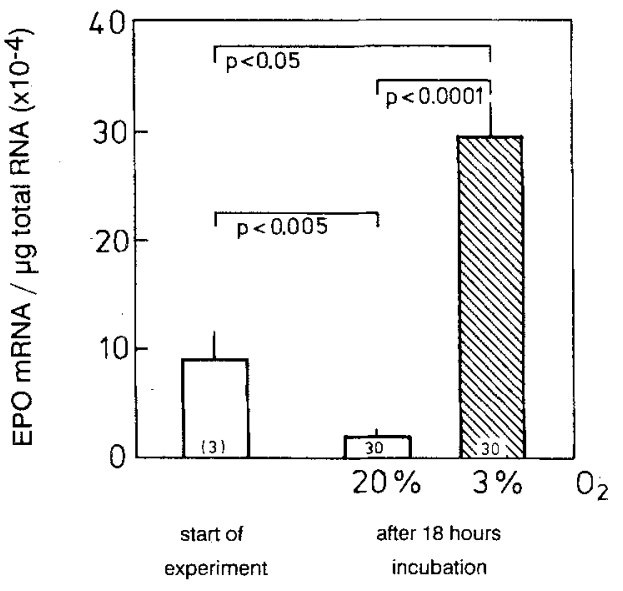

Fig. 2. EPO mRNA levels in primary cultures of rat hepatocytes (mean $\pm \mathrm{SE}$ ). After isolation cells were preincubated for $4 \mathrm{~h}$ at $20 \% \mathrm{O}_{2}$ in the presence of $10 \%$ fetal calf sernm. Cell culture medium was then replaced by serum-free medium, thereby removing non-attached cells. Subsequently (start of the experiment) cultures were incubated for a further $18 \mathrm{~h}$ at $20 \%$ or $3 \% \mathrm{O}_{2}$. EPO mRNA was quantified by RNase protection as described in Materials and methods and the legend of Fig. 1. EPO mRNA levels at the end of the preincubation period and after incubation at $20 \%$ oxygen during the subsequent $18 \mathrm{~h}$ were significantly lower than in cultures incubated at $3 \%$ oxygen for $18 \mathrm{~h}$

a significant reduction of the abundance of EPO mRNA (parenchymal versus initial fraction), and taking into account that approximately 17 times more RNA was extractable from the parenchymal cell fraction than from the non-parenchymal cell fraction, it would appear that the majority of EPO mRNA in the liver of juvenile rats was present in hepatocytes. This is in accordance with the situation in adult animals, in which a recent study, using in situ hybridization and also cell fractionation [33], provided similar conclusions. For subsequent in vitro studies we therefore used established conditions promoting the culture of hepatocytes, i. e. low-speed centrifugation for cell harvest, change of medium to remove non-attached non-parenchymal cells and, except where otherwise indicated, serum-free maintenance conditions.

\section{EPO mRNA levels in cultured hepatocytes}

When hepatocytes obtained from normoxic animals were incubated in vitro, different levels of EPO mRNA were observed, depending on oxygen concentrations in the incubator. As shown in Fig. 2, EPO mRNA was readily detectable in cultures after the 4 -h preincubation at $20 \% \mathrm{O}_{2}$. During the additional $18-\mathrm{h}$ incubation at $20 \%$ $\mathrm{O}_{2}$, EPO mRNA levels declined. In fact, in many single cultures kept at $20 \% \mathrm{O}_{2}$ for this period, EPO mRNA became undetectable with the assay conditions used. Average standardized values of labelled EPO mRNA, however, were slightly above the background level $(P<0.005)$ and comparison of the mean EPO mRNA levels before and after an 18-h incubation allowed an estimate of the mean reduction, which was 4.5 -fold. In contrast, when cultures were kept at $3 \% \mathrm{O}_{2}$ for $18 \mathrm{~h}$, EPO mRNA markedly increased, so that average levels

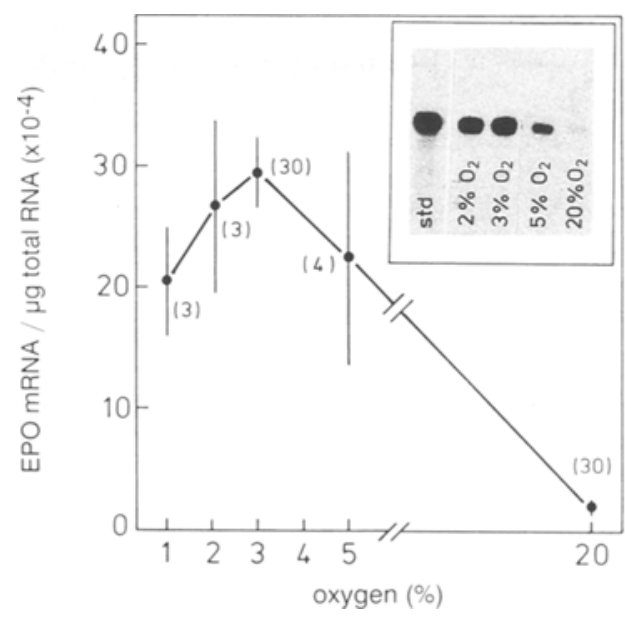

Fig.3. EPO mRNA levels in primary cultures of rat hepatocytes incubated for $18 \mathrm{~h}$ at different oxygen tensions (mean $\pm \mathrm{SE}$ ). Insert shows autoradiograph of an RNase protection assay after 3 days exposure and illustrates an example of the signals obtained with $125 \mu \mathrm{g}$ RNA extracted from cultures incubated at $2 \%-20 \%$ $\mathrm{O}_{2}$. std, protected fragment of a $1-\mu \mathrm{g}$ aliquot of renal RNA that was coanalysed on the gel. EPO mRNA is expressed relative to this external standard as described in Materials and methods and the legend of Fig. 1. EPO mRNA levels in cultures incubated at $1 \%$ and $2 \%$ oxygen were significantly lower than those in cultures of the same cell preparation incubated in parallel at $3 \% \mathrm{O}_{2}$ $(P<0.05$ and $P<0.03$ respectively)

of EPO mRNA after $18 \mathrm{~h}$ were 15 times higher in cultures kept at $3 \% \mathrm{O}_{2}$ as compared to cultures kept at $20 \%$ $\mathrm{O}_{2}$. Supplementation of medium with $10 \%$ fetal calf serum did not change EPO mRNA levels, as compared to parallel cultures incubated under serum-free conditions (not shown).

Figure 3 illustrates EPO mRNA levels in hepatocytes incubated for $18 \mathrm{~h}$ at different oxygen tensions and shows that EPO mRNA levels were maximal at around $3 \% \mathrm{O}_{2}$ in the incubator, while less and more severe hypoxia resulted in somewhat lower EPO mRNA concentrations.

Cell viability, as assessed by trypan blue exclusion, was $92 \pm 3.7 \%$ in freshly isolated cells and $83 \pm 4.0 \%$ after $4 \mathrm{~h}$ of preincubation at $20 \% \mathrm{O}_{2}$ (mean $\pm \mathrm{SE}, n=$ 3 ). The percentage of cells excluding trypan blue after $18 \mathrm{~h}$ of incubation at $20 \%$ and $3 \% \mathrm{O}_{2}$ was $83 \pm 2.4 \%$ and $82 \pm 3.8 \%$ respectively (mean $\pm \mathrm{SE}, n=3$ ) and thus not affected by the reduction in oxygen tensions. Total RNA synthesis, however, as assessed by measurement of $\left[{ }^{3} \mathrm{H}\right]$ uridine incorporation into $\mathrm{Cl}_{3} \mathrm{AcOH}$-insoluble material during the final $2.5 \mathrm{~h}$ of incubation, was $74 \%$ and $56 \%$ lower respectively in cultures kept at $1 \%$ and $3 \% \mathrm{O}_{2}$ than in cultures kept at $20 \% \mathrm{O}_{2}(313 \pm 14$ and $534 \pm 9 \mathrm{cpm} /$ dish compared to $1204 \pm 22 \mathrm{cpm} /$ dish; mean \pm SE, $n=6$ ).

To test if the hypoxia-induced accumulation of EPO mRNA was dependent on gene transcription, cultures were incubated at $3 \% \mathrm{O}_{2}$ in the presence of actinomycin $\mathrm{D}(35 \mu \mathrm{M})$. Addition of actinomycin $\mathrm{D}$ virtually abolished the rise in EPO mRNA [EPO $\mathrm{mRNA} / \mu \mathrm{g}$ total RNA $\left(\times 10^{-4}\right): 296 \pm 0.72$ versus $21.7 \pm 5.2$ in parallel 


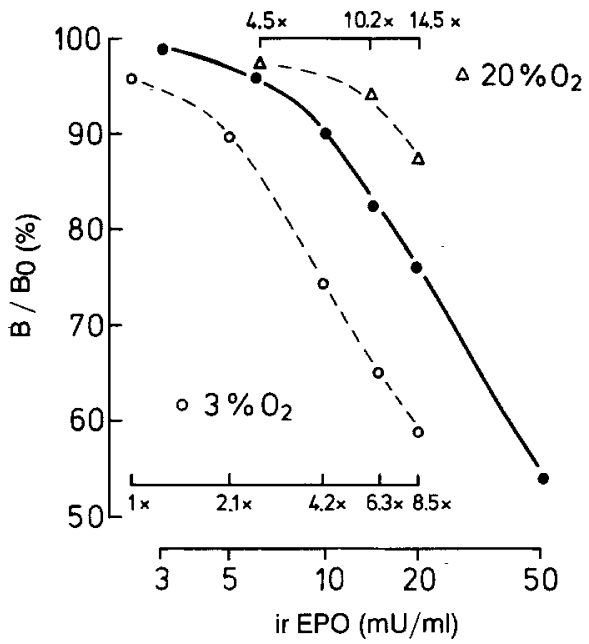

Fig. 4. Radioimmunoassay: dose/response curve for rat EPO (O) and serial dilutions of concentrated culture medium from primary cultures of rat hepatocytes incubated at $3 \%(O)$ or $20 \% \mathrm{O}_{2}(\triangle)$ for $48 \mathrm{~h}$. Concentration factors are given below and above the respective curve. $B / B_{0}$ indicates binding of radiolabelled human EPO to the antiserum in the respective sample in relation to binding in the absence of unlabelled EPO $\left(B_{0}\right)$

cultures incubated at $3 \% \mathrm{O}_{2}$ in the absence of the drug; mean $\pm \mathrm{SE}, n=3]$.

In order to investigate whether increased accumulation of EPO mRNA in hepatocytes kept at $3 \% \mathrm{O}_{2}$ was accompanied by production and release of EPO protein, EPO concentrations were measured in the culture medium after $48 \mathrm{~h}$ of incubation at $20 \% \mathrm{O}_{2}$ and $3 \% \mathrm{O}_{2}$. As shown in Fig. 4, serial dilutions of concentrated culture medium showed a dose/response curve in the EPO radioimmunoassay that paralleled that of rat serum, verifying the presence of immunoreactive EPO protein.
Furthermore, the EPO concentration in pooled medium from cultures kept at $3 \% \mathrm{O}_{2}$ was approximately eightfold higher than in medium from cultures at $20 \% \mathrm{O}_{2}$. However, since concentrations of EPO protein in cell culture supernatant were rather low $(<10 \mathrm{mU} / \mathrm{ml})$ and might not only have reflected hormone production but could also be influenced by variations in secretion as well as possibly clearance of the hormone by hepatocytes, in further experiments we focussed on EPO mRNA determinations as a more direct measure for hypoxia-induced expression of the EPO gene.

To test if the increase in EPO mRNA observed upon lowering the oxygen tension in the incubator could be mimicked by classical pathways of cellular activation, EPO mRNA levels were measured in cells kept at $20 \%$ $\mathrm{O}_{2}$ in the presence of certain agonists or "second-messenger" molecules. To mimic the activation of adenylate cyclase and guanylate cyclase, cells were incubated in the presence of dibutyryl-cAMP $(0.01-3 \mathrm{mM})$, a membrane-permeable analogue of cyclic AMP, or 8-bromocGMP $(0.01-1 \mathrm{mM})$, a membrane-permeable analogue of cyclic GMP. In order to stimulate adenosine receptors, cyclohexyladenosine $(1 \mu \mathrm{M})$ or $5^{\prime}$ - $N$-ethylcarboxamidoadenosine $(1 \mu \mathrm{M})$, stable analogues of adenosine with preferential A1-receptor or A2-receptor affinity respectively [9], were added, and phorbol 12-myristate 13-acetate $(3 \mathrm{nM})$ was used to stimulate protein kinase $\mathrm{C}$ activity [24]. However, as shown in Table 1, none of these substances led to a significant increase in EPO mRNA. At the same time, total RNA synthesis, as assessed by measurement of $\left[{ }^{3} \mathrm{H}\right]$ uridine incorporation into $\mathrm{Cl}_{3} \mathrm{Ac}$ $\mathrm{OH}$-insoluble material during the final $2.5 \mathrm{~h}$ of incubation, was unchanged or only slightly affected (Table 1), indicating that the failure to induce EPO mRNA accumulation was not due to unspecific toxicity.

Table 1. Erythropoietin (EPO) mRNA levels and rates of total RNA synthesis in primary cultures of rat hepatocytes incubated for $18 \mathrm{~h}$ at $20 \% \mathrm{O}_{2}$ in the presence of "second messengers" or agonists"

\begin{tabular}{|c|c|c|c|c|c|}
\hline \multirow[t]{2}{*}{ Substance } & \multirow[t]{2}{*}{ Conc. } & \multicolumn{3}{|c|}{ EPO mRNA $\mu g$ total RNA $\left(\times 10^{-4}\right)$} & \multirow{2}{*}{$\begin{array}{l}{\left[{ }^{3} \mathrm{H}\right] \text { Uridine }} \\
\text { incorporation } \\
\text { (\% of control) }\end{array}$} \\
\hline & & & $\begin{array}{l}\text { Control } \\
20 \% \mathrm{O}_{2}\end{array}$ & $\begin{array}{l}\text { Control } \\
3 \% \mathrm{O}_{2}\end{array}$ & \\
\hline $\mathrm{Bt}_{2}-\mathrm{cAMP}$ & $\begin{array}{l}10 \mu \mathrm{M} \\
100 \mu \mathrm{M} \\
3 \mathrm{mM}\end{array}$ & $\begin{array}{l}0.23 \pm 0.43 \\
0.0 \pm 0.66 \\
2.50 \pm 2.48\end{array}$ & $\begin{array}{l}(0.78 \pm 0.32 \\
(1.36 \pm 2.29 \\
(1.36 \pm 2.29\end{array}$ & $\begin{array}{l}28.1 \pm 4.83) \\
43.8 \pm 4.50) \\
43.8 \pm 4.50)\end{array}$ & $\begin{array}{l}86 \pm 7 \\
84 \pm 4 \\
77 \pm 4\end{array}$ \\
\hline Forskolin & $10 \mu \mathrm{M}$ & $0.70 \pm 1.02$ & $(1.35 \pm 0.97$ & $26.9 \pm 7.31)$ & $104 \pm 3$ \\
\hline 8-Br-cGMP & $\begin{array}{l}10 \mu \mathrm{M} \\
100 \mu \mathrm{M} \\
1 \mathrm{mM}\end{array}$ & $\begin{array}{l}1.07 \pm 1.55 \\
0.0 \pm 0.18 \\
0.38 \pm 0.31\end{array}$ & $\begin{array}{l}(0.78 \pm 0.32 \\
(0.09 \pm 0.04 \\
(0.09 \pm 0.04\end{array}$ & $\begin{array}{l}28.1 \pm 4.83 \text { ) } \\
19.4 \pm 5.20) \\
19.4 \pm 5.20 \text { ) }\end{array}$ & $\begin{array}{r}102 \pm 4 \\
94 \pm 1 \\
96 \pm 4\end{array}$ \\
\hline CHA & $1 \mu \mathrm{M}$ & $0.0 \pm 1.49$ & $(2.06 \pm 2.57$ & $33.1 \pm 4.50)$ & $97 \pm 2$ \\
\hline NECA & $1 \mu \mathrm{M}$ & $0.0 \pm 0.92$ & $(0.78 \pm 0.32$ & $28.1 \pm 4.83)$ & $106 \pm 5$ \\
\hline PMA & $3 \mathrm{nM}$ & $1.26 \pm 1.12$ & $(3.54 \pm 2.30$ & $37.1 \pm 8.50)$ & $97 \pm 5$ \\
\hline
\end{tabular}

a Values are means $\pm \mathrm{SE}, n=3$. CHA, cyclohexyladenosine; NECA, 5'-N-ethylcarboxamidoadenosine; Bt ${ }_{2}$-cAMP, dibutyryl-cAMP; PMA, phorbol 12-myristate 13-acetate. Control cultures for EPO mRNA determinations were parallel cultures from the same cell preparation, incubated at $3 \%$ or $20 \%$ oxygen in the absence of drugs. $\left[{ }^{3} \mathrm{H}\right]$ Uridine incorporation is expressed relative to the value for controls incubated at $20 \%$ oxygen in the absence of drugs, which was $908 \pm 36.1 \mathrm{cpm} / \mathrm{dish}$. In cells incubated at $3 \%$ oxygen the mean incorporation was $52 \pm 5 \%$ of this value 


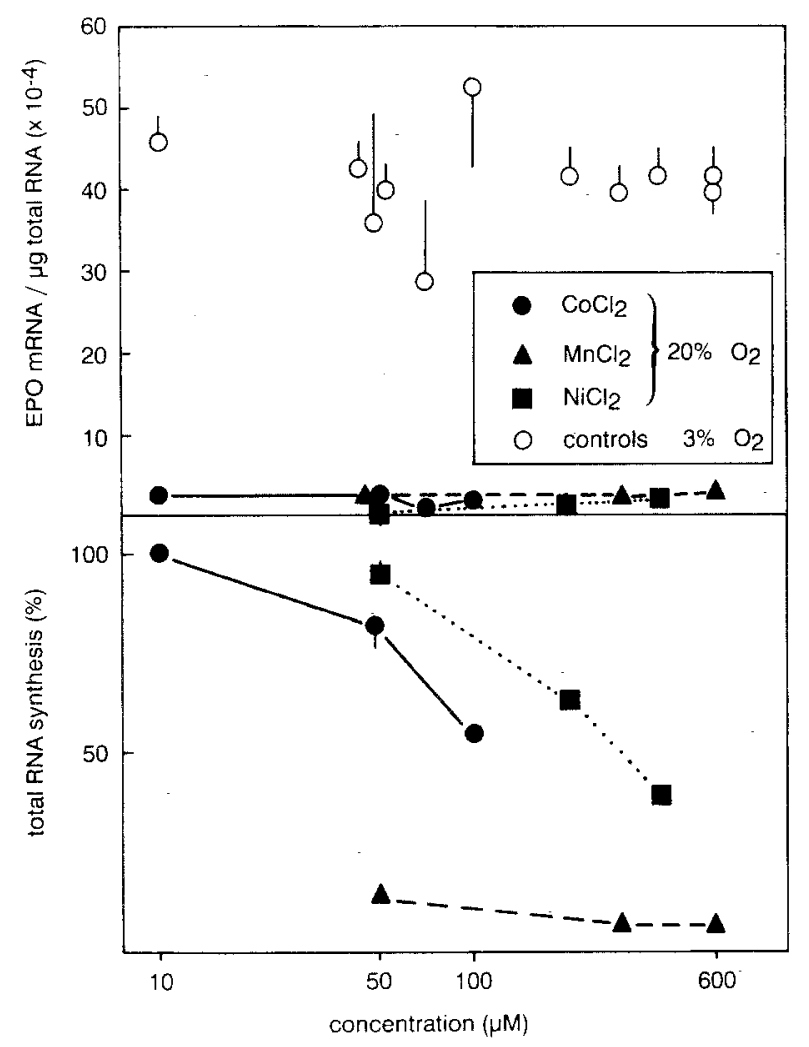

Fig. 5. EPO mRNA levels (upper panel) and rates of total RNA synthesis (lower panel) in primary cultures of rat hepatocytes incubated in the presence of divalent metals (mean \pm SE, $n=4$ for $50 \mu \mathrm{M} \mathrm{CoCl}_{2}$ and $n=3$ for all other points). Total RNA synthesis was assessed as $\left[{ }^{3} \mathrm{H}\right]$ uridine incorporation into trichloroacetic-acidinsoluble material during the final $2.5 \mathrm{~h}$ of incubation and is expressed relative to the value in cultures incubated at $20 \% \mathrm{O}_{2}$ in the absence of metals. $O$, (upper panel) EPO mRNA levels in parallel cultures of the same preparations, incubated at $3 \% \mathrm{O}_{2}$ in the absence of metals. Total RNA synthesis under this condition was on average $44 \%$ of the value in cultures kept at $20 \% \mathrm{O}_{2}$. EPO mRNA was quantified as described in Materials and methods and the legend of Fig. 1

Besides hypoxia the application of certain divalent metals is known to stimulate EPO formation in vivo and in hepatoma cells [14-16]. As shown in Fig. 5, in juvenile rat hepatocyte cultures, however, we did not observe a major increase in EPO mRNA when cells were kept for $18 \mathrm{~h}$ at $20 \% \mathrm{O}_{2}$ in the presence of nickel chloride $(50-400 \mu \mathrm{M})$, manganese chloride $(50-600 \mu \mathrm{M})$ or cobaltous chloride $(10-100 \mu \mathrm{M})$. Only incubation with $50 \mu \mathrm{M}$ cobaltous chloride and $400 \mu \mathrm{M}$ nickel chloride led to slight, albeit significant increases in EPO mRNA as compared to EPO mRNA levels in parallel cultures from the same preparation incubated at $20 \% \mathrm{O}_{2}$ in the absence of metals [EPO mRNA/ $\mu \mathrm{g}$ total RNA $\left(\times 10^{-4}\right)$ : $2.60 \pm 0.77\left(50 \mu \mathrm{M} \mathrm{CoCl}_{2}\right)$ versus 0.81 $\pm 0.64, P<0.05$; $2.01 \pm 0.32\left(400 \mu \mathrm{M} \quad \mathrm{NiCl}_{2}\right)$ versus $0.67 \pm 0.15$, $P<0.03$, mean $\pm \mathrm{SE}, n=3]$. In both instances, however, EPO mRNA levels amounted to less than $7 \%$ of those levels observed under incubation at $3 \%$ oxygen. When cobaltous chloride $(50-100 \mu \mathrm{M})$ was applied for $48 \mathrm{~h}$, no increase in EPO mRNA was observed [EPO $\mathrm{mRNA} / \mu \mathrm{g}$ total RNA $\left(\times 10^{-4}\right): 0.85 \pm 0.47(50 \mu \mathrm{M})$

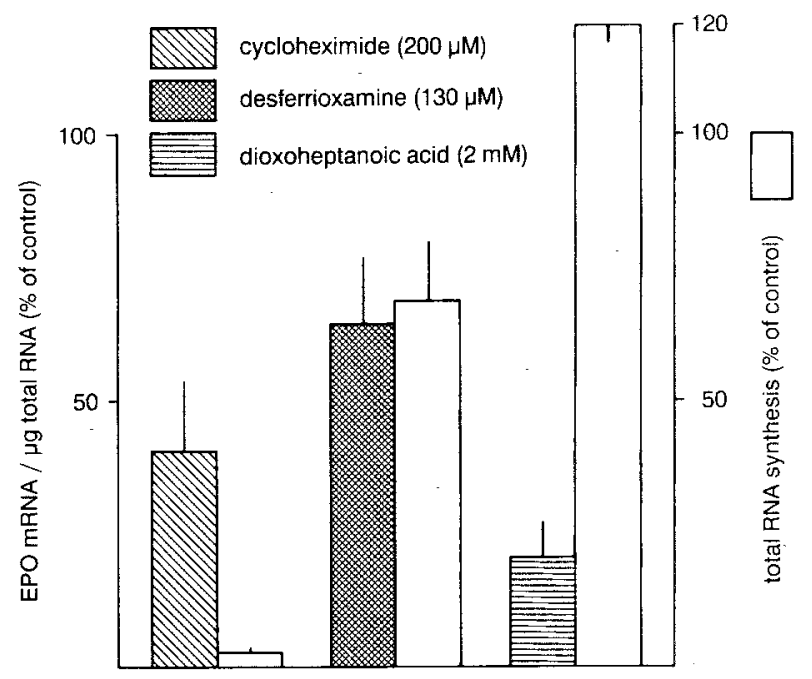

Fig. 6. EPO mRNA levels (hatched bars) and rates of total RNA synthesis (open bars) in rat hepatocytes incubated in the presence of inhibitors of protein synthesis (cycloheximide) or haem synthesis (desferrioxamine and dioxoheptanoic acid) for $18 \mathrm{~h}$ at $3 \%$ $\mathrm{O}_{2}$ (mean $\pm \mathrm{SE}, n=3$ ). $\left[{ }^{3} \mathrm{H}\right]$ Uridine incorporation was determined during the final $2.5 \mathrm{~h}$. Cells were preincubated at $20 \% \mathrm{O}_{2}$ for $4 \mathrm{~h}$ in experiments with cycloheximide and for $24 \mathrm{~h}$ in experiments with desferrioxamine and dioxoheptanoic acid. EPO mRNA concentrations and rates of total RNA synthesis are expressed relative to values in cultures from the same cell preparation incubated in parallel at $3 \% \mathrm{O}_{2}$ in the absence of drugs. Quantification of EPO mRNA by RNase protection as described in Materials and methods

and $0 \pm 1.43 \mathrm{pg}(100 \mu \mathrm{M})$ versus $1.52 \pm 0.28$ and $18.6 \pm 16.9$ in parallel cultures kept at $20 \%$ and $3 \%$ oxygen, respectively, in the absence of $\left.\mathrm{CoCl}_{2}\right]$. $\left[{ }^{3} \mathrm{H}\right] \mathrm{Urid}-$ ine incorporation, as a measure of total RNA synthesis, was markedly reduced by $\mathrm{MnCl}_{2}$ (Fig. 5, lower panel). $\mathrm{CoCl}_{2}$ and $\mathrm{NiCl}_{2}$ also led to a significant, dose-dependent reduction of uridine incorporation, but the effect of these compounds on total RNA synthesis was much less pronounced, and only with $400 \mu \mathrm{M} \mathrm{NiCl}_{2}$ was uridine incorporation lower than in cultures kept at $3 \% \mathrm{O}_{2}$ in the absence of metals, in which it was on average $44 \%$ of the value in cultures incubated at $20 \% \mathrm{O}_{2}$.

In view of the hypothesis suggesting the central role of a rapidly turning-over haem protein in the oxygensensing mechanisms controlling EPO gene expression in hepatoma cells [14], we examined the effects of an inhibitor of protein synthesis, of inhibitors of haem synthesis and of carbon monoxide, which were all shown to inhibit EPO mRNA accumulation in Hep 3B cells [14], on EPO mRNA accumulation in cultured rat hepatocytes incubated at reduced oxygen tensions for $18 \mathrm{~h}$.

As shown in Fig. 6, the addition of the protein synthesis inhibitor cycloheximide $(200 \mu \mathrm{M})$ resulted in a $59 \%$ reduction of EPO mRNA levels. Under this condition, however, total RNA synthesis during the final $2.5 \mathrm{~h}$ of incubation, as assessed by $\left[{ }^{3} \mathrm{H}\right]$ uridine incorporation, was only $2 \pm 1 \%$ (mean $\pm \mathrm{SE}, n=3$ ) of the RNA synthesis in cultures kept at $3 \% \mathrm{O}_{2}$ in the absence of the drug. EPO mRNA accumulation was also inhibited in the presence of desferrioxamine $(130 \mu \mathrm{M})$ ( $35 \%$ reduction), an iron chelator and inhibitor of haem 
synthesis [35] and dioxoheptanoic acid (2 mM) (79\% reduction), an inhibitor of aminolaevulinate dehydratase [40]. During the final $2.5 \mathrm{~h}$ of incubation with these two compounds $\left[{ }^{3} \mathrm{H}\right]$ uridine incorporation was $121 \pm 1 \%$ and $71 \pm 10 \%$ (mean $\pm \mathrm{SE}, n=3$ ) of the value observed in parallel cultures incubated at $3 \% \mathrm{O}_{2}$ in their absence. A reduction in EPO mRNA accumulation was also observed when cells were incubated at $1 \% \mathrm{O}_{2}$ in the presence of $10 \%$ carbon monoxide, which is thought to block haem proteins in the oxy conformation. This reduction of EPO mRNA levels induced by carbon monoxide was on average $37 \%$ [EPO mRNA/ $\mu \mathrm{g}$ total RNA $\left(\times 10^{-4}\right): 11.3 \pm 3.1$ versus $17.4 \pm 5.7$, mean $\pm \mathrm{SE}, n=3]$.

\section{Discussion}

The cell fractionation experiments reported in the present investigation indicate that at least two different cell types, hepatocytes and yet unidentified non-parenchymal cells, contain EPO mRNA in juvenile rat livers, but that in quantitative terms hepatocytes appear to be the major site of EPO gene expression (Fig. 1). Although in our experiments we did not precisely quantify the proportion of EPO mRNA in parenchymal and non-parenchymal liver cells, this is in accordance with results from a recent study in adult rats, where similar conclusions were drawn from EPO mRNA measurements in liver cells separated by different protocols [33]. Thus, it appears likely that the reduction of hepatic EPO mRNA concentrations that occurs with age [12], is not associated with a major change in cell specificity of EPO gene expression, and that hepatocytes are at all stages of development the predominant production site of EPO in the liver.

Our experiments indicate that the ability of hepatocytes to modulate EPO production in an oxygen-dependent fashion is maintained in isolated cells in primary culture (Figs. 2-4). In cells incubated at $20 \% \mathrm{O}_{2}$ for $4 \mathrm{~h}$ plus $18 \mathrm{~h}$ EPO mRNA levels were found to decline during the 18-h incubation period (Fig. 2), which may reflect a decay of EPO mRNA that had accumulated before or during cell isolation, whereas, in contrast, at reduced oxygen tensions, EPO mRNA levels increased during this period. The oxygen-dependent difference in EPO mRNA levels after $18 \mathrm{~h}$ was specific insofar as total RNA synthesis in hepatocytes incubated at low oxygen concentration $\left(3 \% \mathrm{O}_{2}\right)$ was reduced by more than 50\%. Moreover, it appeared to involve gene transcription, since it was abolished in the presence of actinomycin D.

This in vitro system, demonstrating oxygen-dependent regulation of EPO mRNA in cells physiologically producing the hormone in vivo, may have several implications for understanding of EPO regulation. Thus it suggests that oxygen-dependent control of EPO formation in hepatocytes does not essentially require external, e. g. humoral, signals but that intrinsic cellular oxygensensing mechanisms exist. The concentrations of EPO mRNA in cultured hepatocytes were, however, lower than those in hepatocytes isolated from animals that were exposed to hypoxia in vivo (compare Figs. 1 and 2). The progressive decrease of total RNA synthesis that was found with decreasing oxygen concentrations in isolated hepatocytes and the observation that EPO mRNA levels were slightly lower at $1 \%$ oxygen than at $3 \%$ oxygen (Fig. 3) suggest that the level of EPO mRNA in the primary cultures may reflect a balance between hypoxiainduced gene expression and unspecific deterioration of cellular functions. The higher levels of EPO mRNA achieved in vivo thus raise the possibility that in vivo external factors may alter this balance, e. g. by increasing the sensitivity of specific cellular oxygen-sensing mechanisms. Alternatively disruption of tissue structure or culture conditions might blunt the expression of EPO mRNA, as has been observed for other liver-specific genes in cultured hepatocytes [7]. However, more relevant than the absolute level of EPO mRNA in hepatocyte cultures might be the relative amplitude achieved between incubations at ambient $\left(20 \% \mathrm{O}_{2}\right)$ and reduced oxygen tensions $\left(3 \% \mathrm{O}_{2}\right)$, which was approximately $15-$ fold under the conditions used. This amplitude of stimulation is in the same range as that observed in juvenile rats in vivo [12], which seems to support the suitability of hepatocyte cultures for study of EPO regulation.

As a first step to identify possible signal-transduction mechanisms activated by hypoxia, we investigated if the hypoxia-induced accumulation of EPO mRNA in hepatocytes could be mimicked by the addition of classical "second-messenger" molecules or agonists (Table 1). Our results indicate, however, that neither cyclic AMP, cyclic GMP, adenosine or phorbol myristate acetate, used to stimulate protein kinase C activity [24], increase the amount of EPO mRNA in cells cultured at $20 \%$ oxygen. This does not support previous in vitro studies suggesting a central role of cyclic AMP in EPO regulation $[20,21,30,38]$, but is in accordance with observations in isolated perfused kidneys and hepatoma cell lines, where the activation of adenylate cyclase did also not increase basal EPO formation [14, 29, 41]. The evidence of a role for a short-living haem protein operating as oxygen sensor in the control of EPO gene expression in primary cultures of hepatocytes was found to be less conclusive than reported by Goldberg et al. for hepatoma cells [14]. As reported in Hep 3B cells, cycloheximide, dioxoheptanoic acid and desferrioxamine, substances proposed to interfere with the synthesis of such a haem protein $[14,35,40]$ inhibited the hypoxia-induced increases in EPO mRNA levels of isolated hepatocytes (Fig. 6). However, with cycloheximide, total RNA synthesis was virtually abolished, indicating that its specificity is low under the conditions used, and a reduction in total RNA synthesis in parallel with the reduction in EPO mRNA was also observed with desferrioxamine. Divalent metals, such as $\mathrm{CoCl}_{2}, \mathrm{MnCl}_{2}$ and $\mathrm{NiCl}_{2}$, were proposed to stimulated EPO formation in Hep 3B cells by replacing the central iron atom in a putative haem protein, thereby locking it in the oxy conformation [14]. When we added these metals in a wide range of dosages to primary cultures of hepatocytes incubated at $20 \%$ oxygen, a significant increase in EPO mRNA levels was 
Table 2. Rates of $\mathrm{L}-\left[{ }^{35} \mathrm{~S}\right]$ methionine incorporation $(\mathrm{cpm} / \mu \mathrm{g}$ cellular protein) in primary cultures of rat hepatocytes and cultured human hepatoma cells (Hep G2) during an 18-h incubation at $20 \%$ oxygen in the absence or presence of cobaltous chloride ${ }^{a}$

\begin{tabular}{lll}
\hline $\mathrm{CoCl}_{2}$ & \multicolumn{2}{l}{$\begin{array}{l}\left.{ }^{35} \mathrm{~S}\right] \mathrm{Methionine} \text { incorporation } \\
\text { (cpm/ } \mu \mathrm{g} \text { cellular protein) }\end{array}$} \\
\cline { 2 - 3 } & Hep G2 cells & Rat hepatocytes \\
\hline$\overline{50 \mu \mathrm{M}}$ & $\begin{array}{c}1159 \pm 134 \\
976 \pm 45\end{array}$ & $592 \pm 71$ \\
& $564 \pm 46$
\end{tabular}

a Values are mean $\pm \mathrm{SE}, n=3$

only observed with $50 \mu \mathrm{M} \mathrm{CoCl}_{2}$ and $400 \mu \mathrm{M} \mathrm{NiCl}_{2}$ and the values achieved were less than $7 \%$ of the EPO mRNA concentrations observed in parallel cultures after incubation at $3 \%$ oxygen. In contrast, in Hep 3B cells cobalt was reported to raise EPO mRNA levels to $30 \%-$ $50 \%$ of those values achieved under hypoxia $[13,14]$. Our results may thus suggest that in primary cultures of rat hepatocytes the in vitro response to cobalt is less well preserved than that to hypoxia. A failure to stimulate the formation of erythropoietic bioactivity with cobalt has previously also been observed in mixed fetal liver cultures, although these cultures did respond to hypoxia [21]. Moreover, although hypoxia is a consistent stimulus of hepatic EPO formation in vivo, Beru et al. found that treatment of adult rats with cobalt induced hepatic EPO mRNA accumulation only in some animals, but not in others [2], also indicating that the sensitivity of hepatic EPO formation towards hypoxia and cobalt may diverge. Following the concept of a haem protein controlling EPO gene expression, one reason for the failure of cobalt to stimulate isolated hepatocytes more markedly may be that the turnover of such a haem protein is significantly retarded in vitro, which would then not allow a replacement of the ferrous iron in the centre of the porphyrin ring. It is worth noting in this respect that Goldberg et al. reported that hepatoma cells proliferate even in the presence of hypoxia [13], whereas in our experiments the cells did not divide (data not shown). In a first attempt to compare protein synthesis directly in isolated hepatocytes with that in hepatoma cells we measured $\left[{ }^{35} \mathrm{~S}\right]$ methionine incorporation in primary cultures of rat hepatocytes and the human hepatoma cells Hep $\mathrm{G} 2$ during $18 \mathrm{~h}$ incubation in the absence and presence of cobaltous chloride $(50 \mu \mathrm{M})$. In fact, as shown in Table 2, $\left[{ }^{35}\right.$ S $]$ methionine incorporation was lower in isolated hepatocytes than in Hep G2 cells. It is possible, therefore, that a haem protein may well be involved in oxygen sensing in hepatocytes, but that its slow turnover rate makes interference with its biosynthesis difficult. Nevertheless it remains noteworthy that, in the presence of $10 \%$ carbon monoxide, which is considered to block haem proteins in their oxy conformation, EPO mRNA accumulation in hepatocytes was only reduced by approximately $40 \%$, suggesting that a haem protein operating as oxygen sensor would either have to bind carbon monoxide less well than oxygen, or be responsible for only part of the rise in EPO mRNA. Interest- ingly in this respect, also in Hep 3B cells EPO formation was not totally abrogated by carbon monoxide [14].

In summary, using juvenile rat hepatocytes we have established an in vitro system of oxygen-dependent modulation of EPO mRNA that shows characteristics of EPO regulation observed in vivo. EPO regulation in this system, although showing similarities, does not appear to be identical with that in permanent cell lines. Primary cultures of rat hepatocytes may therefore provide a valuable tool for complementing the knowledge about oxygen-dependent EPO regulation.

Acknowledgements. The expert technical assistance of B. Gess and K.-H. Götz is gratefully acknowledged. This work was supported by the German Research Foundation (DFG, AZ KU 859/5-1) and an EMBO fellowship to K.-U. E.

\section{References}

1. Berry MN, Friend DS (1969) High-yield preparation of isolated rat liver parenchymal cells: a biochemical and fine structure study. J Cell Biol 43:506-520

2. Beru N, McDonald J, Lacombe C, Goldwasser E (1986) Expression of the erythropoietin gene. Mol Cell Biol 6:25712575

3. Beru N, McDonald J, Goldwasser E (1989) Activation of the erythropoietin gene due to the proximity of an expressed gene. DNA 8:253-259

4. Bondurant MC, Koury MJ (1986) Anemia induces accumulation of erythropoietin mRNA in the kidney and liver. Mol Cell Biol 6:2731-2733

5. Burlington H, Cronkite EP, Reincke U, Zanjani ED (1972) Erythropoietin production in cultures of goat renal glomeruli. Proc Natl Acad Sci USA 69:3547-3550

6. Caro J, Hickey J, Erslev AJ (1984) Erythropoietin production by an established kidney proximal tubule cell line (LLCPK1) (abstract). Exp Hematol 12:357

7. Clayton DF, Harrelson AL, Darnell JE (1985) Dependence of liver-specific transcription on tissue organization. Mol Cell Biol 5:2623-2632

8. Costa-Giomi P, Caro J, Weinmann R (1990) Enhancement by hypoxia of human erythropoietin gene transcription in vitro. $J$ Biol Chem 265:10 185-10188

9. Daly JW (1982) Adenosine receptors: targets for future drugs. J Med Chem 25: 197-207

10. Doolittle RL, Richter GW (1981) Isolation and culture of Kupffer cells and hepatocytes from single rat livers. Lab Invest $45: 558-566$

11. Eckardt K-U, Kurtz A, Hirth P, Scigalla P, Wieczorek L, Bauer C (1988) Evaluation of the stability of human erythropoietin in samples for radioimmunoassay. Klin Wochenschr 66:241-245

12. Eckardt K-U, Ratcliffe PJ, Tan CC, Bauer C, Kurtz A (1992) Age dependent expression of the erythropoietin gene in rat liver and kidneys. J Clin Invest 89:753-760

13. Goldberg MA, Glass GA, Cunningham JM, Bunn HF (1987) The regulated expression of erythropoietin by two human hepatoma cell lines. Proc Natl Acad Sci USA 84:7972-7976

14. Goldberg MA, Dunning SP, Bunn HF (1988) Regulation of the erythropoietin gene: evidence that the oxygen sensor is a heme protein. Science 242:1412-1415

15. Goldwasser E, Jacobson LO, Fried W, Plzak L (1958) Studies on erythropoiesis. V. The effect of cobalt on the production of erythropoietin. Blood 13:55-60

16. Hopfer SM, Sunderman FW, Fredrickson TN, Morse EE (1991) Increased serum erythropoietin activity in rats following intrarenal injection of nickel-subsulfide. Res Commun Chem Pathol Pharmacol 23:155-170 
17. Jelkmann W (1992) Erythropoietin: structure, control of production, and function. Physiol Rev 72:449-489

18. Koury ST, Bondurant MC, Koury MJ (1988) Localization of erythropoietin synthesizing cells in murine kidneys by in situ hybridization. Blood $71: 524-527$

19. Koury ST, Bondurant MC, Koury MJ, Semenza GL (1991) Localization of cells producing erythropoietin in murine liver by in situ hybridization. Blood 77:2497-2503

20. Kurtz A, Jelkmann W, Sinowatz F, Bauer C (1983) Renal mesangial cell cultures as a model for study of erythropoietin production. Proc Natl Acad Sci USA 80:4008-4011

21. Kurtz A, Jelkmann W, Pfuhl A, Malmström K, Bauer C (1986) Erythropoietin production by fetal mouse liver cells in response to hypoxia and adenylate cyclase stimulation. Endocrinology $118: 567-572$

22. Lacombe C, Da Silva J-L, Bruneval P, Fournier J-G, Wendling F, Casadevall N, Camilleri J-P, Bariety J, Varet B, Tambourin P (1988) Peritubular cells are the site of erythropoietin synthesis in the murine hypoxic kidney. J Clin Invest $81: 620-$ 623

23. McDonald TP, Martin DH, Simmons ML, Lange RD (1969) Preliminary results of erythropoietin production by bovine kidney cells in culture. Life Sci 8:949-954

24. Nishizuka Y (1986) Studies and perspectives of protein kinase C. Science $233: 305-312$

25. Ogle JW, Lange RD, Dunn CDR (1978) Production of erythropoietin in vitro. In vitro $14: 945-950$

26. Paul P, Rothmann SA, McMahon JT, Gordon AS (1984) Erythropoietin secretion by isolated rat Kupffer cells. Exp Hematol 12:825-830

27. Ratcliffe PJ, Jones RW, Phillips RE, Nicholls LG, Bell J (1990) Oxygen-dependent modulation of erythropoietin mRNA levels. J Exp Med 172:657-660

28. Rich IN, Heit W, Kubanek B (1982) Extrarenal erythropoietin production by macrophages. Blood 60:1007-1018

29. Scholz H, Schurek HJ, Eckardt K-U, Kurtz A, Bauer C (1991) Oxygen dependent erythropoietin production by the isolated perfused rat kidney. Pflügers Arch 418:228-233

30. Schooley JC, Mahlmann LJ (1975) Adenosine, AMP, cyclic AMP, theophylline and the action and production of erythropoietin. Proc Soc Exp Biol Med 150:215-219

31. Schuster SJ, Wilson JH, Erslev AJ, Caro J (1987) Physiologic regulation and tissue localization of renal erythropoietin messenger RNA. Blood 70:316-318

32. Schuster SJ, Badiavas EV, Costa-Giomi P, Weinmann R, Erslev AJ, Caro J (1989) Stimulation of erythropoietin gene transcription during hypoxia and cobalt exposure. Blood $73: 13-16$

33. Schuster SJ, Koury ST, Bohrer M, Salceda S, Caro J (1992) Cellular sites of extrarenal and renal erythropoietin production in anemic rats. Br J Haematol 81:153-159

34. Semenza GL, Koury ST, Nejfelt MK, Gearhart JD, Antonarakis SE (1991) Cell-type-specific and hypoxia-inducible expression of the human erythropoietin gene in transgenic mice. Proc Natl Acad Sci USA 88:8725-8729

35. Shedlofsky SI, Sinclair PR, Bonkovsky HL, Healey JF, Swine AT, Robinson JM (1987) Haem synthesis from exogenous 5aminolaevulinate in cultured chick-embryo hepatocytes. Biochem J 248:229-236

36. Sherwood JB, Shouval D (1985) Continuous production of erythropoietin by an established human renal carcinoma cell line: development of the cell line. Proc Natl Acad Sci USA $83: 165-169$

37. Sherwood JB, Robinson SH, Bassan LR, Rosen S, Gordon AS (1972) Production of erythrogenin by organ cultures of rat kidney. Blood 40:189-197

38. Sherwood JB, Burns ER, Shouval D (1987) Stimulation by cAMP of erythropoietin secretion by an established human renal carcinoma cell line. Blood 69:1053-1057

39. Tambourin PE, Casadevall N, Choppin J, Lacombe C, Heard JM, Fichelson S, Wendling F, Hankins WD, Varet B (1983) Production of erythropoietin-like activity by a murine erythroleukemia cell line. Proc Natl Acad Sci USA 80:6269-6273

40. Tschudy DP, Hess RA, Frykholm BC (1981) Inhibition of delta-aminolevulinic acid dehydrase by 4,6-dioxoheptanoic acid. J Biol Chem 256:9915-9919

41. Ueno M, Seferynska I, Beckman B, Brookins J, Nakashima J, Fisher JW (1989) Enhanced erythropoietin secretion in hepatoblastoma cells in response to hypoxia. Am J Physiol 257:C743-C749

42. Watanabe J, Kanai K, Kanamura S (1988) Glucagon receptors in endothelial and Kupffer cells of mouse liver. J Histochem Cytochem 36:1081-1089

43. Widmer U, Schmid Ch, Zapf J, Froesch ER (1985) Effects of insulin-like growth factors on chick embryo hepatocytes. Acta Endocrinol 108:237-244

44. Zucali JR, Stevens V, Mirand EA (1975) In vitro production of erythropoietin by mouse fetal liver. Blood 46:85-90 